\title{
最大ステッピング幅と転倒既往の有無との関係について
}

\section{Does Maximum Step Width Have a Relationship with Fall History?}

\author{
齋藤 孝義 ${ }^{1)}$ 丸山 仁司 ${ }^{2)}$ 菅沼 一男 ${ }^{3)}$ \\ 齋藤 由香里 ${ }^{4)}$ 佐野 徳雄 ${ }^{5)}$ 岩瀬 洋樹 6 )
}

TAKAYOSHI SAITO, RPT, MS ${ }^{1)}$, HITOSHI MARUYAMA, RPT, PhD ${ }^{2)}$, KAZUO SUGANUMA, RPT, PhD ${ }^{3)}$, YUKARI SAITO, RPT, MS ${ }^{4)}$, NORIO SANO, RPT, $\mathrm{MS}^{5)}$, HIROKI IWASE, RPT, MS ${ }^{6)}$

1) Department of Physical Therapy, Faculty of Health Science in Odawara, International University of Health and Welfare: 1-2-25 Shiroyama, Odawara-shi, Kanagawa 250-8588, Japan.TEL+81465-21-6724 E-mail: tsaito@iuhw.ac.jp

${ }^{2)}$ Department of Physical Therapy, Faculty of Health Science, International University of Health and Welfare

${ }^{3)}$ Department of Tokyo Physical Therapy, Faculty of Medical Science, Teikyo University of Science

4) Department of Rehabilitation, Faculty of Health Science, International University of Health and Welfare Atami Hospital

${ }^{5)}$ Department of Physical Therapy, Faculty of Medical Science, Teikyo University of Science

${ }^{6)}$ Department of Rehabilitation, Kurosu Hospital

Rigakuryoho Kagaku 30(6): 877-880, 2015. Submitted Jun. 16, 2015. Accepted Jul. 27, 2015.

\begin{abstract}
Purpose] Elderly subjects were divided into a falls group and a no-falls group, and their maximum anterior and lateral step widths were measured to investigate their relationships with falls. [Subjects] The subjects were 30 persons ( 6 males, 24 females) aged over 65, who could walk independently. [Methods] Based on their history of falls in the past year, the subjects were divided into a falls group and a no-falls group. The maximum lateral and anterior step widths were compared between the groups, and the cutoff value was determined. The correlation coefficients of the maximum lateral and anterior step widths were also determined. [Results] Both the maximum anterior and lateral step widths of the falls group were significantly smaller than those of the no-falls group. Furthermore, between the groups, strong correlations for maximum anterior and lateral step widths were found. [Conclusion] Subjects who can make large steps in the anterior and lateral directions have high motor function, and it is our opinion that a decrease in step width possibly increases the risk of falls.
\end{abstract}

Key words: Maximum step width, elderly, fall

要旨：〔目的〕高齢者を転倒群，非転倒群に分類し前方への最大ステッピング幅・側方への最大ステッピング幅の測 定值と転倒との関係を検証すること.〔対象〕自立歩行が可能な 65 歳以上の 30 名（男性 6 名, 女性 24 名）とした. 〔方法〕過去 1 年間の転倒歴から転倒群と非転倒群に分けた．前方と側方への最大ステッピング幅を群間比較し, カッ トオフ值を求めた．また，前方と側方への最大ステッピング幅の相関係数を求めた。〔結果〕転倒群での最大ステッ ピング幅は非転倒群に比べ前方・側方共に有意に減少した．また， 2 群間とも前方・側方への最大ステッピング幅に て強い相関がみられた。〔結語〕前方・側方ともに大きく踏み出せるものは運動能力が高く、ステッピング幅が低下 することは転倒リスクを増大する可能性があると考えた.

キーワード : 最大ステッピング幅, 高齢者, 転倒

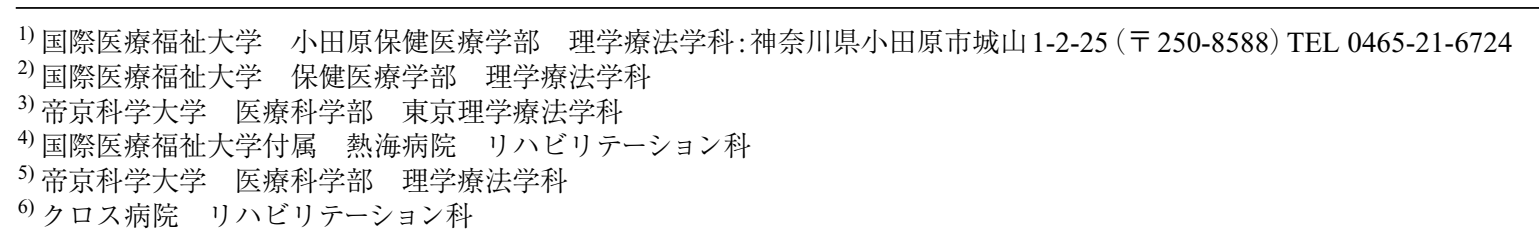

受付日 2015 年 6 月 16 日 受理日 2015 年 7 月 27 日 


\section{I. はじめに}

我が国の転倒の年間発生率は，地域在住高齢者におい て 10〜20\%と報告されており 1,2)，施設の入居者など自 立度や健康状態が低下している高齢者では転倒発生率が さらに高い傾向がある ${ }^{3)}$. 今後もこの傾向は増加すると みられる。そのため, 高齢者の転倒を予測するための研 究が多くなされている.

転倒を予測する指標として臨床の現場では様々な評価 方法が検証されている. timed up \& go test（以下, TUG) 4) $10 \mathrm{~m}$ 歩行 5) は歩行能力やバランス能力を反 映すると言われており，臨床でもよく使用されているテ ストである。しかし，ある程度の広さを確保しなければ ならないことや歩行不安定者を測定するにあたり転倒リ スクの観点から見ればより安全な評価方法が必要である と考える。また, 広さの確保を必要とせず安全, 簡便に 測定できる評価方法として Functional reach test（以下， FRT）がある。臨床でよく使用されている一方，FRTの 測定值が転倒群と非転倒群の間に有意な差が認められな かった 6,7) とする報告や, FRTよりも下肢筋力低下など 別の項目が転倒リスクファクターとする報告もある ${ }^{8)}$. このようにFRT は転倒との関係を必ずしも明確に示さ れていないと考える. FRTの他に近年, 敏捷性テスト が注目されている。池添らはステッピングテストにおい て運動機能や転倒との関連を示唆し, 転倒リスクの高い 者を予測するテストとして報告した ${ }^{9)}$ 。若年者と転倒リ スクのある高齢者を比較した場合，若年者では姿勢が乱 れて転倒しそうになっても 1 歩前に足を踏み出して踏ん 張ることによって，姿勢を立て直すことができる。しか し，転倒リスクのある高齢者では 1 歩の大きさ（ステッ プ長）が若年者と同程度であったとしても 1 歩のステッ ピングだけでは立ち直りきれずに, 複数回ステッピング が続いた後, そのまま前方へ転倒することや 1 歩踏み出 した時に側方へバランスを崩して転倒する傾向があ る10)，そのため，できる限り支持基底面から重心を移 動し姿勢を保つことができるかについて検証することは 転倒のリスクを考えるうえで非常に重要であると考え た。

本研究は, 高齢者を転倒群, 非転倒群に分類し前方へ の最大ステッピング幅および側方への最大ステッピング 幅と転倒との関係を検証することを目的とした。

\section{II. 方法と対象}

\section{1. 対象}

対象は自立歩行が可能な 65 歳以上の高齢者 30 名（男 性 6 名，女性 24 名）とした。平均年齢は $77.2 \pm 7.8$ 歳, 平均身長は $155.5 \pm 7.2 \mathrm{~cm}$, 平均体重は $51.3 \pm 10.2 \mathrm{~kg}$ であった (平均值 \pm 標準偏差)。過去 1 年間の転倒経験
の有無を聴取し転倒経験のある者（以下，転倒群）と転 倒経験がない者 (以下, 非転倒群)に分類した。転倒群 · 非転倒群の分類には Gibson の定義 11)に従い「本人の意 思ではなく，地面またはより低い面に身体が倒れるこ と」とし, 歩行以外での階段昇降や自転車の乗り降りな どによる転倒は除外した。転倒群は 17 名（男性 1 名, 女性 16 名）で, 平均年齢は $79.1 \pm 6.8$ 歳, 平均身長は $153.0 \pm 7.3 \mathrm{~cm}$, 平均体重は $48.2 \pm 9.8 \mathrm{~kg}$, 非転倒群は 13 名（男性 5 名, 女性 8 名）で平均年齢は $74.8 \pm 8.8$ 歳 平均身長は $158.8 \pm 5.8 \mathrm{~cm}$, 平均体重は $55.2 \pm 9.7 \mathrm{~kg}$ であった。対象者は，測定に影響を及ぼすと考えられる 下肢整形外科疾患ならびに中枢神経疾患などを有する者 は除外した。本研究の目的・内容を十分に説明し，同意 を得た後に参加の意思を示した者を対象とした。なお， 本研究は国際医療福祉大学研究倫理審査委員会の承認を 得て行った（承認番号 14-Ig-62）.

2. 方法

前方への最大ステッピング幅，側方への最大ステッピ ング幅の測定に先立ち，検者が被験者に対し実施方法を 口頭で説明しながらデモンストレーションを行い, 被験 者が測定方法を理解した後に十分な練習をさせた。測定 の開始肢位は両上肢を体側に下垂し, 両踵の距離を $10 \mathrm{~cm}$ 開けた立位とした。測定方法は，床面に目印にな る線を引き両側のつま先を線に合わせた後, 一方の下肢 を可能な限り前方へ踏み出した。測定はメジャーを使用 し目印になる線から足のつま先までの距離を測定した。 踏み出す足は被験者の自由とし，1歩踏み出した際に， 踏み出した肢位を保つことができなかった場合は, 再度 測定を行った。測定は 3 回実施し, 最大值を小数点第 2 位で四捨五入した.

側方への最大ステッピング幅の開始肢位は, 踏み出す 足の第 5 中足骨を床面に引いた線に合わせた立位とし た。 その後, 可能な限り側方へ踏み出した。測定はメ ジャーを使用し開始肢位の第 5 中足骨先端から踏み出し た最も遠い第 5 中足骨先端までの距離を測定した。踏み 出す足は被験者の自由とし, 踏み出した肢位を保つこと ができなかった場合は除外し，再度測定した。測定は 3 回とし, 最大值の小数点第 2 位で四捨五入した，統計学 的手法は転倒群と非転倒群の群間比較には対応のない $\mathrm{t}$ 検定を用いた。また Receiver Operating Characteristic (以 下， ROC）曲線を用いて最大ステッピング幅と側方へ の最大ステッピング幅について転倒群と非転倒群を最適 分類するためにカットオフ值を求めた。ささらに前方への 最大ステッピング幅と側方への最大ステッピング幅の関 係についてはPearsonの相関係数を求めた. 統計ソフト ウェアは SPSS Statistics21 を使用し有意確率 5\%未満を もって有意と判断した. 
表 1 転倒群, 非転倒群におけるステッピング幅の群間比較 単位： $\mathrm{cm}$

\begin{tabular}{lcc}
\hline & 転倒群 $(\mathrm{n}=17)$ & 非転倒群 $(\mathrm{n}=13)$ \\
\hline 前方への最大ステッピング幅 & $76.4 \pm 12.7^{*}$ & $90.5 \pm 11.3$ \\
側方への最大ステッピング幅 & $74.4 \pm 15.3 *$ & $87.9 \pm 10.1$ \\
\hline
\end{tabular}

平均值 \pm 標準偏差, $*: \mathrm{p}<0.01$.

\section{III. 結 果}

転倒群と非転倒群の年齢，身長，体重に有意差は認め られなかった。転倒群と非転倒群の群間比較の結果, 前 方への最大ステッピング幅, 側方への最大ステッピング 幅ともに転倒群が有意に低值を示した。（表 1）また, ROC 曲線から前方への最大ステッピング幅のカットオ フ值は $81.7 \mathrm{~cm}$ （感度 0.82 , 特異度 0.85 ）であった。 側 方への最大ステッピング幅は $78.5 \mathrm{~cm}$ (感度 0.77 , 特異 度 0.77）であった。次に転倒群の前方への最大ステッ ピング幅と側方への最大ステッピング幅の相関係数は $\mathrm{r}=0.959$, 非転倒群での前方への最大ステッピング幅と 側方への最大ステッピング幅の相関係数は $\mathrm{r}=0.849$ で あった. 転倒群, 非転倒群とも前方への最大ステッピン グ幅，側方への最大ステッピング幅との間に強い相関が みられた。

\section{IV. 考 察}

本研究は高齢者を転倒群, 非転倒群に分類し前方への 最大ステッピング幅および側方への最大ステッピング幅 を実施することで最大ステッピング幅と転倒との関係を 検証することを目的とした。

本研究の結果, 転倒群, 非転倒群の群間比較において どちらの測定值についても転倒群で有意に低值を示し た。 また，前方への最大ステッピング幅と側方への最大 ステッピング幅の測定值において転倒群, 非転倒群の ROC 曲線からカットオフ值を求めた結果, カットオフ 值は前方への最大ステッピング幅は $81.7 \mathrm{~cm}$, 側方への 最大ステッピング幅は $78.5 \mathrm{~cm}$ であった. 前方への最大 ステッピング幅, 側方への最大ステッピング幅ともに， 転倒群の測定值が低值であったことから, ステップ動作 能力の低下が転倒のリスクを高めると考えられ，前方へ の最大ステッピング幅, $81.7 \mathrm{~cm}$ 側方への最大ステッピ ング幅, $79.5 \mathrm{~cm}$ を境界に高齢者では転倒のリスクが増 大すると考えた，前方への最大ステッピング幅，側方へ の最大ステッピング幅ともに片脚立位になり一側の下肢 で安定した立位を保持したうえで他方の足をステップす る必要がある。市橋10) は, 片脚立位は立位のバランス 指標として用いることができ, 開眼条件においても片脚 立位時の重心動摇は 50 歳代以降に増大し, 60 歳代, 70 歳代ではその増大がさらに顕著となったと述べている。
高齢者は加齢に伴いバランス能力が低下するが, 転倒を 引き起こすリスクの高い高齢者はバランス能力や筋力が より低下していると考えられる。 そのため, 片脚立位と なり遊脚肢を前方・側方にステッピングする運動は高齢 者にとって難易度が高い運動であったと考えられる。こ のことから, 片脚立位となり大きく 1 歩を踏み出せる者 は運動機能が高く転倒リスクが低いと推察される. 岡田 ら 12) は高齢者になると加齢に伴い男女とも歩幅が小さ くなる傾向があると述べている. 高齢者の歩行の特徵と して歩幅の減少があげられる．若年者と高齢者が同一速 度で歩行する場合, 若年者では歩幅を増大させるが, 高 齢者では歩数の増加によって補う。これも高齢者では歩 行時の立脚期に一側の下肢で安定した姿勢を保持できな いためであると考えられ，より大きく 1 歩を踏み出せる 者は, 運動機能が高いと考えられる.

次に, 転倒群, 非転倒群共に前方への最大ステッピン グ幅と側方への最大ステッピング幅に強い相関が見られ た. 前方への最大ステッピング幅と側方への最大ステッ ピング幅ともに片脚立位となりステッピングを行う動作 であり，どちらも支持している下肢の安定性が求められ る。本研究の結果からは, 転倒群, 非転倒群ともに前 方・側方のステッピングの相関が高いことから, どちら か片方の測定を行うことで転倒のリスクを評価できる可 能性があると考える。しかし，転倒に至る原因は「つま ずき」「すべり」「よろめき」などが考えられる。「つま ずき」は前方向へ転倒しやすいと考えられ，「よろめき」 は側方への転倒となりやすいと考えられることから転倒 の発生状況などの分析が必要である.

本研究の限界は, 転倒群, 非転倒群の分類が過去の経 験をもとにしていることから想起バイアスが考えられ る。また，転倒は内的要因のみでなく外的要因なども影 響するので転倒の状況などを精査するとともに運動機能 と転倒との関係について前向きの研究による検討を行う 必要があると考えた。

\section{引用文献}

1) 原田 敦, 松井康素: 高齢者の転倒と骨折. 整形·災害外科, 2002, 45(7): 715-722.

2) 安村誠司, 金成由美子: 高齢者における転倒と骨折の疫学. The Bone, 2003, 17(3), 237-241.

3) 新野直明：運動障害 1) 転倒. Geriatric Medicine, 1998, 36(6): 849-853. 
4) Podsiadlo D, Richardson S: The timd 'up \& go' a test of basic functional mobility for frail elderly persons. J Am Geriatr Soc, 1991, 39(2): 142-148.

5) 衣笠 隆, 長崎 浩, 伊東 元 ·他：男性（18８3歳）を 対象にした運動能力の加齢変化の研究. 体力科学, 1994, 43(5): 343-351.

6) Hallmann HW: Comparison of elderly nonfallers and fallers on performance measures of functional reach, sensory organization, and limits of stability. J Gerontol A Biol Sci Med Sci, 2001, 56(9): M580-M583.

7) Daubney ME, Culham EG: Lower-extremity muscle force and balance performance in adults aged 65 years and older. Phys Ther, 1999, 79(12): 1177-1185.

8) 金 憲経, 吉田英世, 鈴木隆雄・他：高齢者の転倒関連恐
怖感と身体機能一転倒外来受診者について一. 日本老年医 学会雑誌, 2001, 38(6): 805-811.

9) 池添冬芽, 市橋則明, 島 浩人 ・他：高齢者の転倒を予 防するためのステッピングテストの有効性. PTジャーナル， 2009, 43(11): 989-995.

10) 市橋則明：高齢者の機能障害に対する運動療法 第3 刷. 文光堂, 東京, 2011, pp40-42.

11) Gibson MJ: Falls in later life. In: Improving the health of older people-A world view, Kane RL, et al. ed., Oxford University Press, New York, 1990, pp296-315.

12) 岡田真平, 上岡洋晴, 小林佳澄・他：農村在住高齢者の移 動能力・バランス能力とその関連事項に関する考察一北御 牧村研究一. 身体教育医学研究, 2001, 2(1): 13-20. 